\title{
An Ethnographic Analysis of Escort Services in Poland: An Interactionist Approach
}

\author{
Izabela Ślęzak \\ University of Lodz, Poland
}

DOI: http://dx.doi.org/10.18778/1733-8077.16.4.08

\section{Keywords: \\ Sex Work; Symbolic Interactionism; \\ Grounded Theory; \\ Ethnography}

\begin{abstract}
In the Polish literature on the subject, prostitution is analyzed from various theoretical perspectives, but, first of all, from the perspective of social pathology. This approach makes the researchers focus mainly on the social maladjustment of women providing sex services and the reasons for their violation of the normative order.
\end{abstract}

In my ethnographic research conducted in escort agencies in Poland, I was willing to go beyond this narrow outlook. I have adapted an interactionist perspective to analyze the escort agencies as organizations where intense interactions between employees, as well as employees and clients, take place, the sex work process is organized, and the meanings of prostitution are negotiated. I conducted the analysis according to the procedures of the grounded theory methodology. It allowed me to see and describe such processes as: (re)defining the situation of providing sex services from vice to work, sex work as a collective action, performing sex work, secondary socialization for sex work.

The adaption of an interactionist perspective opens some new directions for analysis, which could help to understand the phenomenon of women getting involved in and continuing to provide sex services for a long time.
Izabela Ślęzak, PhD, is an Assistant Professor in the Department of Sociology of Organization and Management, Institute of Sociology, Faculty of Economics and Sociology of the University of Lodz. Main spheres of scientific interests focus on the methodology of social research, especially qual- itative methods, symbolic interactionism, sociology of work and organization. Currently performing field studies related to the phenomenon of sex work.

email address: iza.slezak@gmail.com 


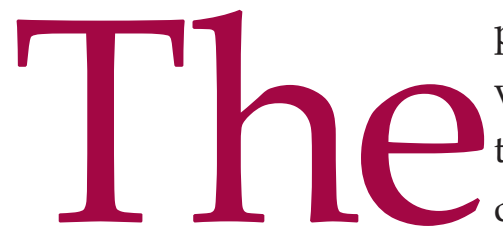

provision of sex services has aroused controversy for a significant part of the history of this phenomenon (Roberts 1992). Since the turn of the $19^{\text {th }}$ and $20^{\text {th }}$ centuries, that is, when new scientific disciplines emerged (including sociology, criminology, and psychology), scientists have become important participants in the discourse on prostitution. The fascination with positivism (Błońska 2010:280) and scientism led to the development of deterministic theories that explained why women engaged in this socially condemned act. One of the most popular concepts was that of a "born prostitute" by Lombroso and Ferrero (2004), presented in the book entitled Criminal Woman, the Prostitute, and the Normal Woman. Although this work was thoroughly criticized in later years, it was an inspiration for subsequent generations of researchers. The interest in the prostitution etiology, which is rooted in positivism (though no longer from the perspective of biological, but rather the social factors that increase the probability that a given woman will become involved in prostitution), exerted a great impact on the research carried out in the first half of the $20^{\text {th }}$ century (and it perhaps does so nowadays as well).

This is well visible in the research carried out in Poland, which has been dominated by the normative perspective. Researchers usually asked the question "why," focusing on the reasons why women break social norms related to sex life. They also sought specific socio-demographic features of women who had decided to earn money in this way. The researchers wanted to know which variables, or combinations of variables, are "responsible" for someone getting involved in prostitution. The results of these studies were to serve preventive and rehabilitation purposes (cf. Ślęzak 2019:23). This perspective dominated the research carried out in the Polish People's Republic in the second half of the $20^{\text {th }}$ century (Jasińska 1967; Podgórecki 1969; Antoniszyn and Marek 1985). In the new reality, after the socio-political transformation, ${ }^{1}$ the phenomenon of prostitution in Poland was still researched from the perspective of social pathology (Kowalczyk-Jamnicka 1998; Jędrzejko 2006; Gardian 2007; Pospiszyl 2008; Welskop 2013). The only change was the extension of the research field to questions related to the spread of AIDS and sexually transmitted infections (STIs) (Izdebski 2012). Exceptions include the research carried out from a different perspective, which includes the symbolic and interactional dimension of prostitution (Wojciechowska 2012; Surmiak 2015; Ślęzak 2019). However, they constitute a minority of the research conducted in Poland.

Meanwhile, the interpretative approach has a significant body of work in the field of research into non-normative sex behaviors. Many highly inspiring studies have been conducted by researchers from the Chicago School (e.g., Thomas 1923; Reckless 1933) and members of the later generation of Chicago sociologists (Leznoff and Westley 1956; Reiss 1961; Goffman 1963; Gagnon and Simon 1973). The tradition of the Chicago School of Sociology has exerted an influence on subsequent generations of researchers (Heap 2003; Sanders 2006:450; Kleinknecht 2007:222). From the perspective of my research interests, especially important is the book by Robert Prus and Styllianos Irini, entitled Hookers, Rounders, and Desk Clerks (1988). This is a study of the social organization of the hotel com-

\footnotetext{
${ }^{1}$ The process of transforming from a socialist into a democratic system started in Poland in 1989 in a peaceful manner. These changes were also accompanied by economic (the development of a free market based on private ownership), social, and moral transformations.
} 
munity, which includes women looking for men interested in sexual services in a hotel bar. In their analysis, the authors try to provide a thorough, highly detailed account of people's lived experiences from the viewpoint of the participants and the ways that they entered into the group life as agents (Prus 2009). Prus and Irini analyze the activities of "hookers, strippers, and other entertainers, of bartenders, waiters, waitresses, desk clerks, and other hotel staff, and a variety of hustlers and thieves, as well as an extended assortment of patrons" (Prus 2009:238). They focus on how these people get entangled in role sets, interaction systems, and small social groups, analyzing their relationships, activities, and identities (Prus and Irini 1988; Kleinknecht 2007:231). It is an interesting approach because numerous studies of deviations describe the situation of people involved in only one deviant role or one sphere of activity (Kleinknecht 2007:230). Apart from this, most research on deviance focuses on a set of factors, variables, structures, or forces that are presumed somehow to cause certain effects (crime and deviance as dependent variables). Thus, Prus and Irini adopted a completely different perspective, perceiving deviation as a social process rather than the product of people's individual qualities or vague sociological notions of social structure (Prus 2009). At the same time, the authors did it in a manner free from sensationalism, moralism, and remedialism. The book is, therefore, an example of how an approach inspired by symbolic interactionism and an ethnographic approach can offer a new perspective on the phenomenon of prostitution.

The abovementioned approaches to the research of prostitution provided the context and reference point for my project (Ślęzak 2019). While analyzing the provision of sex services in escort agencies,
I adapted a perspective that was different from those that dominate in the Polish literature on the subject. I analyzed the escort agencies as organizations where interactions take place that influence the course, time, and level of involvement of the female workers in prostitution. This perspective emerged during the empirical research when I noticed that the interviewees define escort agencies as a place of work. I derived the theoretical inspiration to analyze the gathered data from the interactionist sociology of work (cf. Konecki 1988) and other concepts rooted in the interpretative paradigm. This allowed me to focus on the perspective of the researched individuals, the way they experience everyday life, and how they deal with various aspects of the way they earn. I believe that the focus on the social organization of sex work broadens the area of scientific inquiry. It also allows a deeper understanding of this phenomenon and its dynamics (Ślęzak 2019). In this article, I would like to present the most significant consequences of this choice for the research results.

\section{Data and Research Methods}

While choosing the appropriate research methods and techniques, I was inspired by the works of researchers from the Chicago School of Sociology, who, in the 1920s, started to use methods known from anthropology to study new problems related to the development of large cities (Angrosino 2010:26). Particularly suggestive was Park's call to researchers-he proposed "getting your hands dirty in real research" (Gobo 2008:35). It meant leaving their offices, going into the field, and observing real situations in the urban space. In subsequent years, students of Park and Burgess developed the tradition of ethnography, contributing to its popularization in sociology (Prus 1996:119). While 
planning my research project, I wanted it to match this way of conducting research (Angrosino 2010). However, it proved difficult to achieve these aims. The main barrier was the distrust that the people running escort agencies had towards me, and this resulted in the lack of consent to stay on the premises and carry out observations for an extended period (cf. Ślęzak 2018a; 2018b). Eventually, after several months of attempts, I managed to begin the ethnographic research. It was possible thanks to a recommendation of a person trusted by the owner of one of the escort agencies. It was one of the longest operating and largest premises in the city (at various times, from a dozen to about 30 women worked there). ${ }^{2}$ After obtaining permission to start the research, I conducted multi-stage negotiations on when, how, and what I will be able to observe. Initially, I carried out my (overt) observations to a limited extent (during the day and at times set by the boss of the agency), which was expanded as I gained their trust. Eventually, my research in this agency took 4.5 years. I visited it once a week on average, but at certain periods much more often, spending there several hours talking and observing. It allowed me to establish closer relations with the women who worked there. I have been meeting many of them regularly for several weeks or even months when they worked in the researched agency. I reestablished contacts with some of them who returned to work after a few years' break. This made it easier for me to get their consent for the interview, especially that it was quite typical for new employees to find out about my research from their coworkers and decide to take part in it before I even met them personally in the agency. In subsequent years, I gained the opportunity to carry out

\footnotetext{
${ }^{2}$ A more detailed description of how escort agencies operate in Poland is provided in the next two sections.
}

my observations in three other places. These were medium-sized premises, with between a few and a dozen women working there at the time of the research. When compared to the first agency, my visits to the other three were shorter. Since I conducted my research in agencies that were operating regularly, I could not always be there for long, and when I wished to observe specific events, considering the theoretical sampling procedure. Therefore, my presence in the researched agencies often consisted of making the most of the opportunities I had. Eventually, the scope of my involvement depended on (and resulted from) negotiations with individuals who managed the premises, and with their employees.

I conducted the whole project between 2007 and 2013 in Lodz, in four escort agencies. All of the premises where I conducted the research had good opinions among clients and employees. One agency operated on two shifts (day and night), the others only during the night. I supplemented my observations with interviews carried out with all categories of agency employees (the women providing sex services, the security workers, and the bosses). The most important group of data is the interviews with the women who provide sexual services (56 interviews). The interviewees worked in agencies where I conducted observations, and they gave informed consent to participate in the study. Their experience in the escort agencies varied (from a week to 14 years), as did their ages (from 18 to 56 years old, most of them in the range between 20 and 35), earnings (from several hundred to several thousand PLN per month, even more in some periods), and the level of satisfaction with this way of earning money. The vast majority of the interviewees were very open during the interviews, so they were quite long and lasted from 35 to 290 minutes 
(90 minutes on average). Some of the employees of the agencies where I conducted research did not agree to be interviewed, ${ }^{3}$ but they talked to me during my visits to the premises. Their perspective (e.g., information on the workers' relations or interactions with clients) was also taken into consideration while drawing my conclusions.

In the ethnographic research project, I decided to apply the analytical procedures of grounded theory in the version proposed by Barney Glaser and Anselm Strauss in The Discovery of Grounded Theory (1967) and later developed by Anselm Strauss and Juliet Corbin in Basics of Qualitative Research (1990). I intended to introduce more systematic tools for planning and carrying out subsequent research steps through the application of the constant comparative method, theoretical sampling, coding, writing, and sorting theoretical notes (Glaser and Strauss 1967; Strauss and Corbin 1990; Konecki 2000). I started the analysis in the first weeks of the research, with open coding of transcriptions from the interviews and notes from the observations. I analyzed the data in the ATLAS.ti (4.2) computer software, and I also used ATLAS.ti to carry out the selective coding. I created memos from the very beginning, from code notes to theoretical memos, which later underwent theoretical sorting. Theoretical diagrams, graphs, and fourfold tables were the auxiliary tools that supported the conceptualization, as they showed the links between particular categories. Furthermore, I carried out axial coding based on the coding paradigm; the conditional matrix was also an important inspiration for me.

\footnotetext{
${ }^{3}$ The reasons for refusals varied from their lack of time or unwillingness to be interviewed at the expense of resting between meetings with the clients to a reluctance to make a self-reflection and reveal private information to a stranger (cf. Ślęzak 2018b).
}

The main categories generated during the analysis (Ślęzak 2019) were: the social construction of the work situation in escort agencies, work with the client in the lounge and the room, security and safety work, work on building a team of female employees, the process of becoming a member of a team of female employees, and the identity work of the sex workers. Each of them included many detailed subcategories (e.g., the work with the client in the lounge category included subcategories such as the selective and non-selective choice of clients, strategic seduction, incidents in the lounge, and groups of clients). Inspiration for the data interpretation came from concepts developed by leading representatives of symbolic interactionism in the scope of work, for example, interactional work or the social organization of work (Strauss et al. 1985). Thus, the final shape of my analysis was the result of adapting the symbolic interactionism perspective as the main theoretical framework. Evaluating my project from a distance, I think that this led to some interesting results. I believe it made it possible to deepen the existing knowledge on the provision of sex services in escort agencies by drawing attention to the processes omitted in research based on other paradigm assumptions. These issues will be developed below.

\section{The Socio-Legal Context of the Indoor Sex Work in Poland}

The difficulties in obtaining permission to research in the escort agencies, described above, resulted from the legal context in which such premises operate in Poland. Under Polish law, the provision of sex services is not illegal, but the activities of third parties, that is, those who intend to encourage, facilitate, benefit, or force prostitution (also human trafficking for prostitution) [Arts. 203, 204 of the 
Criminal Code of the Republic of Poland 19974]) are criminalized. The only non-penalized form of providing sex services is individual sex work. However, in practice, there have been plenty of premises operating in Poland since the 1990s, which, although officially offering hotel services, massages, or the organization of events, actually act as intermediaries in the provision of sex services. These premises are quite well-rooted in the urban space and, apart from some cases when there are also other forms of breaking the law (human and/or arms trafficking, drug selling), they operate without major obstacles. ${ }^{5}$

A dominant form of premises where sexual services are offered are private flats, where one or several women accept clients acquired primarily through Internet advertisements. They are called apartments. These are individual initiatives undertaken by one or several women, who share the costs of maintaining the flat, and none of whom holds any managerial functions. There are also premises managed by a person who does not provide sex services but organizes the working conditions of women and charges a commission (usually about $50 \%$ of the rate for each client). In Poland, the premises organized this way are called escort agencies, even though they generally provide stationary services, within the premises, so they rather resemble a brothel (see: Ślęzak 2018b). In the course of my research, travel services (to hotels or clients' flats) were becoming rare due to the organizational dif-

\footnotetext{
4 See: https://www.legislationline.org/download/id/7354/file/ Poland_CC_1997_en.pdf. Retrieved September 18, 2020.

${ }^{5}$ It is rarely the case in Poland that the agencies are being shut down due to police operations; however, there is such a risk, which results in mistrust and reluctance expressed by the premises' managers towards strangers (meaning, those who are neither workers nor clients) who show interest in their operation.
}

ficulties related to their implementation (providing transportation and security for employees during the meeting). Since, in Poland, it is not possible to legally employ women to provide sex work, they do not have any employment contracts or are employed in fictitious-hostess, bartender, masseuse, dancer-positions that do not correspond with their actual job description. All of the rules of the work (from working time to salary) are established based on a verbal agreement and are not formally recorded. Such premises are organized in flats (similarly to the abovementioned private initiatives of women) or in premises that have been adapted to run such a type of activity (e.g., there are: a dance pole, a bar with alcohol, a lounge with sofas where workers spend time with their clients, plenty of rooms for individual meetings with the clients, facilities for female workers). A client who would like to use the services of the premise is entertained in the lounge, where all female workers gather. The client chooses the one with whom he will spend some private time in the room. Depending on the premises, the selection is made either very quickly, mainly based on the assessment of physical appearance, or it is preceded by extensive interactions, using the available infrastructure of a given premise. It is worth noting that while women who work with clients in the apartments usually do so during the day and evening (for safety reasons and to maintain proper relations with the neighbors), agencies mainly operate in the evenings and nights, and possibly also during the day if the number of female employees is sufficient to do so.

The researched escort agencies were diverse in many terms, among others, the organization of work, financial outlays for infrastructure, but, first of all, the management styles, which I will describe in the next section. 


\section{The Management Styles}

Based on the collected data, I have distinguished four main management styles (Ślęzak 2019:62-74) carried out by the bosses of the researched escort agencies, and other premises where my interviewees previously worked. They were:

- an oppressive style $e^{6}$ implemented by those for whom running an escort agency was a way to obtain extraordinary profits, regardless of the costs incurred by the employees. The premises run in such a way were subject to physical, sexual, financial, and psychological violence on the part of the boss (but also of other employees, e.g., bar or security staff and clients) against women who often felt powerless or financially dependent enough on the job at hand to be unable to change or leave it. In many cases, the bosses abused psychoactive substances, under which they made inconsistent and/or extreme decisions. These premises were characterized by a low level of security, care of sexual health, or mental well-being of the female workers.

- a style based on excessive fraternization that appeared when bosses could not find the balance between running a place and having fun. The bosses who adapted this style saw their escort agency as a place for entertainment not only for the clients, but also for themselves and, to some extent, their workers. As a result, they took various psychoactive substances and encouraged the female workers to take them too; they had affairs with their female workers, were active

${ }^{6}$ I did not get permission to conduct observations on oppressive premises. I received information about them from my key informants. The remaining styles were developed on the basis of observations and interview data. parties in personal conflicts, and were unable to establish satisfactory rules of the work. On premises managed this way, there was, for the most part, no violence against female workers, but it was an unstable workplace.

- a style based on distanced professionalism-when bosses perceived and ran their premises as a business enterprise, formulating and enforcing rules "as in standard work" (e.g., punctuality, a notice of absence, leave, the prohibition of psychoactive substances, obligation to perform periodic medical examinations). They also introduced a (not always transparent) system of financial penalties for breaking the rules.

- a style based on kind professionalism, similar to the previous one, but with less distance between the workers and the boss. Usually, the bosses did not exercise any financial penalties, but they rather tried to build a system of personal involvement of the female workers-due to, for example, offering advantageous work conditions, the loss of which was not worth risking, and assigning some empowering tasks (e.g., allowing deciding about the improvements to be implemented on the premises, taking the workers' side in any dispute with the client).

The last two styles were characteristic of the most stable, predictable, and safe workplaces.

The described styles show the diversity of women's work situations in escort agencies. The place where a woman worked had an impact on her career, but also influenced the way she thought about herself and her job. The more oppressive the premises where the woman worked were, and the more time 
they spent there, the greater was the risk of experiencing the negative consequences of prostitution, also in the biographical context. The mere awareness that there are different styles of managing the premises (which is not obvious for the novices) is extremely important because it gives them the feeling that they are not condemned to work in unfavorable conditions. As the sex services market in Poland can be seen as the employee market, there have been very dynamic personnel changes on many premises. Usually, however, the employees left the premises without notice and without confronting their bosses. They thus avoided the need to justify their decision and the possible risk of the boss trying to make their departure difficult. However, some of the female workers decided to stay and work on the premises where the management style did not suit them entirely, but the work offered some significant advantages, for example, the agency was popular among the clients and ensured good profits. In such situations the female workers manifested an attitude of conformist adaptation, becoming a "perfect employee," or they tried to negotiate the working conditions to make them more acceptable.

Those workers who knew how to model their relations with the boss to adapt them to their needs, or who decided to change the premises, were capable of minimizing the disadvantageous aspects of work and using all advantages of cooperating with the agency when compared to providing sex services individually, without any organizational facilities.

\section{The Provision of Sex Services from the Perspective of Symbolic Interactionism: The Main Categories}

The categories I generated while coding and writing memos were strongly rooted in the collected data.
At the same time, the most important categories that formed the core of my analysis were influenced by the concepts of symbolic interactionism. To show this relationship, I will present the most important categories below.

\section{(Re)Defining the Situation}

One of the most important categories was the process of defining situations by the interviewees, which was related to redefining the phenomenon of providing sex services (and one's involvement) from vice to work. ${ }^{7}$

The literature on the subject (including studies based on the results of research carried out in Poland in recent years) is dominated by analyses of prostitution as a pathological phenomenon. ${ }^{8}$ The same tone is used in media coverage and when shaping the figure of a prostitute in popular culture. The interviewees noticed the lack of social acceptance for the way they earned money, and some of them internalized this negative perspective. When they started providing sex services, they felt a dissonance between how they perceived themselves and how (in their opinion) society perceived them. For some of the interviewees, the mere fact of entering the agency was proof of their "fall," which, according to them, was-as an interpretation-clear and obvious for other people. One of the interviewees described how she tried to enter the premises unnoticed:

\footnotetext{
${ }_{7}$ I use the term "work" following my interviewees, who described their actions in this way. However, this did not result from the knowledge of the postulates of the sex workers' rights movement, which the participants of the study did not know about.

${ }^{8}$ Not only in Poland, as it seems. A similar pattern can be observed in other countries with an abolitionist approach to prostitution (Dziuban and Ratecka 2018).
} 
The first agency...I went there...And it was a separate mansion, and I was walking around the house for probably THREE HOURS and waited for the right moment when no one would be walking from any side of any street because there were two streets on the side of that agency. I was already tired of waiting to call there. And I just had enough. I was already discouraged BEFORE I even managed to use the intercom. Finally, I seized such a moment that one marriage was coming closer from a distance, I remember that, and I waited for that person to come down and open it for me [the door] because I felt that they were getting closer. [woman, 28 years old, 6 years of indoor sex work]

It is worth noting that in the above case it was about passers-by, strangers. Much more intense fear and shame were associated with the risk of being noticed near the agency, or even more so-inside, by a friend or a family member. Therefore, since starting to work in an escort agency was seen as a moment of transition, of breaching the social roles which the women should play according to the cultural message, the division into decent and fallen women became an important category for the interviewees.

At the very beginning, when I came to the agency, the girls wanted to make me coffee or some tea. I was disgusted and I was thinking: "God, what am I doing here? From a decent home, a decent mom, a decent father, a decent brother, me too, what am I even doing here?" I thought to myself: “God, I'm leaving, I'm leaving," and, believe me, I couldn't get up from the chair, because I was sitting in the chair and I couldn't get my ass up, like my ass got into that chair and I couldn't get up at all. And I had remorse for a very long time. I have a husband, a daughter, a six-year-old daughter, I lie to my husband. [woman, 34 years old, 6 years of indoor sex work]
Negative emotions connected with providing sex services were often reflected in difficult beginnings in the agency. The women who saw their decisions as a sign of social fall had difficulties establishing proper relations with their clients and coworkers. Some of them avoided any interactions whatsoever, others were incapable of setting inviolable boundaries in relations with others because they were convinced that whatever (bad) happened to them would be well-deserved and "normal" (cf. Ślęzak 2017):

I'm afraid that I will get an aggressive or unpleasant client, and what am I going to do then? I don't know. That's where I am, doing what I do, I came here myself, so I just have to put up with it. [woman, 43 years old, 3 months of indoor sex work]

The interviewees rather shared the vision of prostitution as a vice and of an agency as a potentially dangerous place that threatens their physical safety but also undermines their former social position.

Along with developing experience in the provision of sex services in escort agencies, the participants of the study redefined their involvement in prostitution. Instead of seeing it as a pathology, they began to perceive it as work, a job that brings money. This was the basic interpretative frame of the interviewees who had more experience of working in an escort agency:

I couldn't settle at the beginning at all. I mean, it's not about the girls, but generally about the whole situation. But, then you somehow think differently, that it's my job now, so I go to work to make some money, and that's it. A client is a client. And that's all. So I think differently now, and I feel much better. Lighter. [woman, 22 years old, 4 months of indoor sex work] 
You do what you do and treat it as your job. And that's it. And when I say it this way to myself, it's ok, but when I start to analyze it, to overthink it, it gets bad, very bad [sighs]. [woman, 34 years old, 6 years of indoor sex work]

To analyze the process of redefining what prostitution is, I adapted the work concepts developed in the field of symbolic interactionism by Hughes and Strauss. Strauss adopted a very broad definition of work and perceived it in any enterprise, even if the involved individuals did not think of it as work (Strauss et al. 1985:290). Thus, even though in traditional definitions (Konecki 1988:240; cf. Szczepański 1961:17) prostitution is rarely provided as an example of work, it may be analyzed as such from the perspective proposed by Strauss. This opened new paths to interpret the actions undertaken by women working in escort agencies, in the context of their professional role and attunement in the group of the employees of the premises. I will return to these issues later in this article.

Interestingly, in explaining the role of prostitution in social life, the perspective of the research participants was similar to the concept of dirty work proposed by Hughes and developed by his followers. Hughes (1958:91) noticed that the division of work in society is not only based on technical, but also on psychological and moral criteria. Therefore, the concept of dirty work can refer to those actions and professions which are considered by society to be repulsive or degrading in a physical (e.g., related to dirt, waste, bodily fluids, death, dangerous working conditions, etc.), moral (thought of as sinful, immoral), and/or social aspect (where it is necessary to serve others, have contact with stigmatized or excluded people) (Ashforth and Kreiner 1999). Some occupations are burdened in only one of the listed dimensions, while other jobs, for example, prostitution, touches all of those aspects ${ }^{9}$ (Drew, Mills, and Gassaway 2007a:4). As a consequence, dirty work has low social prestige and is allocated to individuals and groups who should act on behalf of society. They fulfill tasks that most of us would prefer to avoid, but that someone should do ("It's dirty work, but somebody's gotta do it!" [Drew, Mills, and Gassaway 2007a:5]). The concept developed by Hughes (and its further interpretations) allows us to see prostitution from a different perspective and perceive escort agencies as organizations that carry out dirty work (Ślęzak 2019). It is worth stressing that such an interpretation frame was not obvious for novice female workers. It was the other women who had been earning in the same way for longer who taught the novices about the significance of prostitution for society (e.g., that it has always existed, it helps to fulfill the sexual needs of men without damaging their marriages, that members of socially respected professions [doctors, lawyers, police officers, priests] use such services, etc. ${ }^{10}$ ). They also imposed a definition of the situation as work and working (namely, coming to the agency-a workplace with specific working hours and rules, employee roles, and networks of relationships with other workers):

We also work like any other person; it's always been like that. Prostitution has always been there, and it always will be. [woman, 29 years old, 4 years of indoor sex work]

\footnotetext{
${ }^{9}$ But, it must be remembered that it is more a social construct than an objective feature of an occupation described in this way.

${ }^{10}$ The interviewees used techniques of neutralization (Sykes and Matza 1957): denial of injury, denial of the victim, condemnation of the condemners, but also denial of responsibility (external factors prompted them to engage in sexual services), and appeal to higher loyalties (thanks to prostitution, women can provide better living conditions for their children, help sick parents, etc.).
} 
I always say to the girls that this is a job. You go as if it were a normal job; you start and end at a specific time. So it's like a normal job. [woman, 50 years old, 6 months of indoor sex work]

Thanks to the individual experience and knowledge acquired from their colleagues, the interviewees also redefined what work in the agency consists of. It is worth noting that while describing it during the interviews, they often focused on aspects other than sexual, for example, necessary acting skills, being a good listener, giving advice and comfort, negotiating, managing interactional crises. This shift in emphasis allowed them to bring prostitution closer to the socially respected professions (actress, ${ }^{11}$ therapist, psychologist), and thus deal with the ambivalence of the initial period of work:

I mean, yes, I've set it up in my psyche that, yes, I come here and play very well, I'm an actress here and play very well, tra-la-la-la-la, the client chooses, et cetera. And then I leave and I'm a completely different person, I go to my husband and I miss him, I want to hug him, and so on. You have to separate it somehow because you'd go nuts! You would go nuts. [woman, 30 years old, no information on seniority in indoor sex work]

Some people come here to complain about their family, about the trouble at work, and you listen, and you listen like a psychologist. [woman, 34 years old, 6 years of indoor sex work]

This perspective made it easier for the novices to redefine their involvement in the provision of sex services. It turned for them from being a vice into a pro-

${ }^{11}$ The interviewees very often used theatrical metaphors to describe their experiences of working in the agency. I will come back to this issue later in the text. fessional choice and a strategy of being in the labor market, which they perceived as being unfriendly for women and offering them the worst possibilities of earning (temporary work, undeclared work, lowpaid work in services). An example may be provided by the situation of one of the interviewees who, due to her incomplete education and the resulting difficulties in the labor market, worked in precarious jobs. To increase her income, she tried to combine several full-time jobs allowing her to fulfill her life needs. She saw the provision of sex services as a more effective job, thanks to which she could resign from "normal" but poorly paid and physically strenuous jobs:

You can't always live off a normal job, and I worked two jobs for a few months. I had a normal job, and I still worked there when I came here. I worked in [name of the company] and also in [name of the company]. I woke up every day at half-past three in the morning, and I came back home at eleven in the evening, and I concluded that this was [pause] that I was not at home at all, and I actually make no money too. And I need to earn some more somehow. [woman, 41 years old, 2 years of indoor sex work]

However, a society that is protected from dirty work stigmatizes the people who carry it out (Hughes 1964:52). It is often the case that members of the marginalized groups carry out marginalized work, or their work is trivialized (as with, for example, the work of women or immigrants [Drew, Mills, and Gassaway 2007b:237]). The participants of the study also experienced stigmatization, which was expressed multiple times during the interviews:

Society perceives it as something bad [sadly]. Sure, something bad. That we are the worst scum, whores, uh, and I don't know, we do it without a condom, and 
we are here for pleasure. Some clients think that we're here for pleasure because they ask what I am doing here [jokingly]. And I'm earning money! In a sense, it's a different job, but it gives you money, and that is the basis of all this work here. [woman, 30 years old, 9 years of indoor sex work]

Fear of social reactions meant that despite the process of redefining the situation, the interviewees did not interpret their involvement in sex work in the same way as other jobs they had done before. Many of them were afraid of the consequences of revealing information to their close relatives about the provision of sexual services. They were sure that their relatives would not share their perspective and would interpret their actions as a deviation or a vice:

NOT EVERY person will understand me; one will condemn me, DAMN, and kick me; "ordinary whore, scum," he will say to me because THAT'S WHAT people are like. Another man will be like, "I feel sorry for her." And yet another one will say, "It might not be the best solution for this person, but it might be the ONLY ONE." [woman, 34 years old, 6 years of indoor sex work]

As a consequence, for many of the interviewees, defining prostitution as a job was related to ambivalent feelings, in particular, if (e.g., during an interview) they adopted the perspective of an external observer who is assessing their lives from the point of view of socially acceptable standards.

Defining prostitution as work can be interpreted as a symptom of moving to the next phase of their career $^{12}$ in sex work. This change was related to a shift

${ }^{12}$ Cf. Becker et al. 1961; Goffman 1961; Becker 1963; Hughes 1964; 1997; Konecki 1988; Prus and Irini 1988; Prus and Grills 2003. in identity that was taking place through a number of sub-processes of both the individual (I refer here to the concept of identity self-work proposed by Konecki [2007]) and collective (when dealing with other actors of the world of prostitution) identity work (Ślęzak 2010; 2014). In my analyses, I focused particularly on the collective dimension of these changes, adapting the perspective of sex work as a collective action.

\section{Sex Work as a Collective Action}

Analyzing how the women reported the change in their perspective of perceiving sex services drew my attention to the collective dimension of work and social organization of sex work in escort agencies (Ślęzak 2019). A new employee of an escort agency learns the meanings related to prostitution from the other social actors. ${ }^{13}$ They provide a set of collective beliefs, norms, cognitive scripts, and, ultimately, the strategies and tactics of sex work. Thanks to them, a novice female worker can cope with the negative emotions related to the first period of work faster and build stable motives to stay in prostitution. Other women working in an agency play a special role in this process. It is worth stressing that my interviewees, when shifting the definition of prostitution from vice to work, also shifted their perception of other women who earned this way. Based on stereotypes, they expected to meet women addicted to psychoactive substances, aggressive, and vulgar. However, upon closer acquaintance, it turned out that most of the coworkers were ordinary women, with similar life paths to those of the interviewees, having the same life challenges and problems:

${ }^{13}$ Becker (1953) drew attention to similar issues in his study on cannabis smokers, emphasizing the role of more involved participants in the learning process of a new, unknown social role which is perceived as deviant. 
I wasn't expecting it either, I imagined it all differently. I imagined this world differently. That it would be more predatory, more outrageous, I thought I'd meet some girls who are already, you know what. And these are NORMAL girls. There are a lot of normal girls. Wives to husbands, mothers to children. [woman, 28 years old, 3 years of indoor sex work]

Defining the coworkers as similar to themselves opens a path to intensive interactions which are of crucial importance in the process of secondary socialization (I will return to this thread in a further part of the paper). Coworkers can also provide mental support and show how to deal with difficulties at work, referring to their example. Examples of such actions are provided in an interview with a woman who describes how she helps a newcomer to go through the initial period of work:

A while ago a nice girl started working here. She comes from far away, has large debts, and she comes here for weekends. And she's VERY shy...she sometimes asks me if it was so tough in the room for me, so I tell her, "It will PASS." She's sitting here in the corner, and, on the one hand, she wants to be picked, so that she'll have money and so on, but on the other, she has some reluctance, so she sits; we push her so she sits closer to the client, not in the corner because no one can see her there. She's very reluctant. [woman, 39 years old, 3 years of indoor sex work]

At this point, it should be mentioned that the relationship between the workers is extremely dynamic. Such relations include not only socializing actions or support at work but also rivalry and sometimes even aggression towards each other. These processes can be very intensive, especially at the time of lower customer traffic or regrouping of the group hierarchy after hiring a new employee.
These can take the form of hostile actions-from ignoring and teasing to foul competition, which can take the form of pranks, intimidation, provocations, and even physical violence (fights) (Ślęzak 2019:100-104):

I once heard that they poured some glue in that girl's shoes. And in that previous place, they put some bleach in the girl's lipstick. She already has big and red lips, but when she put the lipstick on, I think she realized quite quickly, but they were very red! She went home immediately. [woman, 23 years old, 4 years of indoor sex work]

When one girl earns more or something like that, they want to DESTROY her. Because the girls come from different backgrounds, and you can expect ANYTHING. That they'll cut her clothes, destroy her shoes, take clothes from each other, it's normal. Maybe it's not normal, but it can be expected. [woman, 31 years old, 5 months of indoor sex work]

In the case of the oppressive management style and a style based on excessive fraternization, coworkers try to discipline those colleagues who break unwritten work rules (e.g., customer rates, the scope of services, use of condoms, etc.). In extreme cases, this is a way to force an unacceptable colleague to leave the agency. The effectiveness of these actions depends primarily on how the boss of the premise will react to them (Ślęzak 2019:105):

[A female worker describes the adapted provocations-IŚ] Eventually, either she leaves herself or you approach the boss in such a manner that HE is the one who dismisses her, but it doesn't mean he will do that, because if a girl earns money, it's obvious she also earns for him. So, it depends on the boss, whether he thinks logically. Because if he's intelligent, he 
won't get caught up in such manipulations. [woman, 31 years old, 5 months of indoor sex work]

Although relations between coworkers may take some destructive forms, in the long run, the work in the agency forces women to cooperate. Like in other types of work (e.g., Becker 1982; Strauss et al. 1985), the sex work in an escort agency is possible thanks to the cooperation of numerous people (cf. Prus and Irini 1988). Strauss and colleagues noticed that it is impossible to do the work without the permanent interactions of many people who negotiate, renegotiate, persuade, inform, and order them to do the work (Strauss et al. 1985; Konecki 1988). The analysis of the interactions among all participants of the world of escort agencies leads to analogical conclusions. The provision of sex services in an escort agency means playing a set of roles. Some of them are played for the other women working in the agency (the potential roles include the role of a colleague that you cooperate or compete with, a friend, a mentor, etc.). Different roles are played for the male coworkers (bosses, security workers, bartenders, taxi drivers), for whom you can be a trusted colleague and partner in small agency scams, "the right hand," a subordinate, a victim of bullying, harassment, or physical violence, an "ordinary" employee, et cetera. A separate category of interactional partners are clients in front of whom a whole series of roles are played, not only those that refer to sexual, but also to emotional expectations (for example, a professional who satisfies non-standard sexual needs, a lover, or a girlfriend).

Therefore, work in an escort agency is a joint action of numerous people who fit together and adjust their actions (cf. Blumer 1969:70). Despite the common belief that the provision of sex services covers only the interaction between a woman and a client, it involves teamwork in the case of escort agencies. The workers present themselves to the clients in the lounge as a group, which forms a coherent performance intended to make a specific impression on the clients (cf. Goffman 1959). Although each worker individually attempts to seduce the client, they together try to build an atmosphere of erotic fun, which will encourage the man to visit this particular agency:

I think that we all come here to earn some money, and we should stick together, cooperate to shake some money out of this guy, and not to sit sullenly in the lounge. Because when the guys come in a group, they also feel it, and this one guy once said to us, "There's this unhealthy atmosphere here. These girls are sitting, one in this corner, another one over there." Because when the girls like each other, they are cheerful, they sit together and have fun, they create a nice atmosphere, so the guy gets involved, he also has fun and is more willing to spend his money. But, when one girl sits in one corner, and the other girls are in another corner, and they say nothing to him, he feels the atmosphere is not like he would want it to be. It has to be fun; he must have a lot of fun to leave his money here. [woman, 35 years old, 4 years of indoor sex work]

The clients become an audience, but at the same time, they form a team (cf. Goffman 1959), presenting themselves in front of the women in a particular way (e.g., playing the role of someone wealthier or tougher/bolder than they are):

It's worse when three or four of them come, and one pretends to be such a hero in front of the others. But, when you take them to the room, they're so quiet and nice. He's so macho, but only in front of his friends. And he's so timid in the room as if he wasn't there 
at all. They're like children! Like children! [woman, 35 years old, 1 year of indoor sex work]

When there's a group, everyone shows off in front of their friends. And it's most intensive in the lounge. [woman, 30 years old, 4 years of indoor sex work]

Sex work in social agencies is, therefore, interesting space for analyzing the interactive and dramatic aspects of work.

\section{Performing Sex Work}

The analysis of the interactional work carried out in the escort agency by various categories of social actors draws attention to the process of performing sex work. This is an important issue because, as Konecki noticed, sociologists of work often do not deal with the work process itself. They usually research the employee's mental traits, their social position, or the result of work. As a consequence of such analyses, the sociologists lose the problem of how a person works, how they are linked to other people in a particular work situation, and what is the division of work and its temporal entanglement (Konecki 1988).

While conducting ethnographic research in social agencies, I paid a great deal of attention to the interactions between all the participants in these organizations. They make up the work process that takes place both in the lounge (in the presence of others) and in the room (usually only between the employee and the client). While observing the women's activities in the lounge, I created the category of strategic seduction, that is, the process of a worker gaining a client. This is how I draw attention to the fact that women who provide sex services are not only passive participants of the interaction (it is not that they are merely selected by the clients), but they actively create the situation of a meeting with a client, encouraging or discouraging him from further interactions:

You sit down in the lounge, you talk about prices, smile at him. So, he sees you. And when you sit in the corner [curls up, pretends to be sad], you don't give a shit about him. And when you sit and try to, like, chat, it's obvious that he sees you're interested in him, so it's normal that you would like him to choose you. Of course, a lot depends on us, on our approach! You need to have an approach! If you sit in the corner-you won't get paid. [woman, 30 years old, 9 years of indoor sex work]

It is also interesting which techniques the women use to discourage clients from a meeting. In this case, it is not only the effectiveness of that action that is important but also the form of the action itself. The workers are willing to interact in such a way that the client feels that he was the one who turned down the meeting. If he does not feel offended by the woman's behavior (but is satisfied that he avoided an unsuccessful interaction), he might decide to meet another worker, which will be reflected in the agency's profit. Furthermore, such actions reduce the risk of any possible criticisms from the agency manager, as the workers usually should not refuse to meet clients-except for the cases of aggression or other dangerous behaviors:

When you don't want to go to the room, you just sit, look at the ceiling, or whatever; you can pick your nose [laughter], or, for example, when he comes to sit with you...for example, I don't know, I sit next to him, and if there's nobody around and no one hears it, you say that you have your period and you can't work, that you're sore. The period is the best solution, or that I'll do nothing in the room if he wants any 
extras. I say all of this to discourage him, but not in anybody's presence; but, when he chooses me, we go to the bar to pay, and then I'm like, "No, come, let's sit and talk," and then I tell him all this stuff so he doesn't choose me. [woman, 23 years old, 4 years of indoor sex work]

The analysis of the women's narratives considering the course of meetings with clients also allowed me to generate categories related to various types of work during such meetings. I refer here to the concept by Strauss and colleagues (1985) who observed many types of medical work performed by hospital staff and patients, and even by their family members. Based on the analysis of actions undertaken by the escort agency workers, I differentiated various types of work that they perform during the meetings with the clients, for example, working (with/on) the client's body, parapsychological work, work on the relationship, "feeling" the client, and safety work. Effectively combining all types of work during an interaction with a client (and each client has individual expectations) is a challenge for the workers. It requires not only careful observation (a client does not always express their expectations verbally and directly) but also flexibility in tailoring their actions to the changing situation:

It depends on the girl and the client. Each client is different and should be approached differently. You observe the client, what he's doing. Some clients like hugging, because they lack this warmth from a woman. And others just want to have sex. They do what they need to, and they leave. It's really different. [woman, 40 years old, 3 years of indoor sex work]

The analysis of the sex work process shows that prostitution-commonly seen as not requiring any skills-is a complex work on the interactional level.

\section{Secondary Socialization}

While analyzing the work of women in escort agencies, I treated these premises as organizations (Ślęzak 2019). On the grounds of symbolic interactionism, the organizations are perceived as being designed, produced, maintained, and changed in everyday interactions (Konecki 2006:11). Therefore, the organization brings together numerous groups and people within the process of continuously creating and maintaining a collective action (Konecki 2006:13). While analyzing the agencies as organizations and workplaces, I paid more attention than is usual in research on prostitution to secondary socialization, understood here as socialization for sex work, but also socialization to a specific workplace, namely, the escort agency (Ślęzak 2019:118-122). The latter process should be understood as more than just an apprenticeship. It is also the process of transferring the sets of rationalizations, neutralizations, and ways of dealing with social stigma. The secondary socialization makes it possible to carry on with the provision of sex services by silencing the women's doubts and their emotions of shame (Cooley 1922:184-185), which I have already mentioned. It also makes it possible to build the role of an agency worker, based on observations of actions undertaken by the coworkers:

Some girls who were there a little longer, even a month, in an agency, they know something more about it, so I ask them about everything...how they do it, more or less, so the client doesn't cheat in some way or anything. To make money. They have their ways. When they go into the room with the client, they are not like... like... like afraid or something, but they are... they feel at ease simply, and they are completely different. [woman, 43 years old, 3 months of indoor sex work] 
Observing the behavior of other workers, who apparently do not feel such strong negative emotions and, in some way (which is unclear for the newcomers), managed to cope with the difficulties of the first period of work, allows the beginners to believe that it is possible and perhaps it will also happen to them:

I am troubled every time I have a client, but I think I can do it somehow. The girls somehow treat it normally, but I'm like... I'm happy that I've been chosen because it's money, but, on the other hand, I go with the client, and I'm shaking. [woman, 43 years old, 3 months of indoor sex work]

During my analysis of the secondary socialization process, I was interested in the context of role-taking/role-making (Turner 1962) during interactions with all categories of participants of this world, but also the process of changes in identity (which I have already stressed). The key factor in these processes is that the coworkers become a reference group, whose system of values and cognitive perspective are taken for granted (Shibutani 1962:130-132). This makes it easier for newcomers to define prostitution as work and to accept the rules in a given team of female colleagues. Depending on what is considered a normal and desirable working pattern in a team, a newcomer behaves differently towards the clients and coworkers. The following quote provides an example:

So, a client comes in, and all the girls pounce. They kiss him and do everything; they sit on his lap, hug him, get undressed, dance on those poles. It's a real fight for the client. I sat there like [eyes and mouth wide open] shocked, totally shocked. It was a completely different system of working at night there. And here we're these innocents; we go out, we sit down. For example, only E. does the striptease here, and you need to pay for this, and only one girl does it. And in that place all the girls undress, they dance to the music, simply to present themselves to the client. So it's not for me. I think it's like the girls have more courage there, they have this personality, they can work with every client. [woman, 28 years old, 6 years of indoor sex work]

The values and standards of the coworkers also influence the attitude of employees towards taking psychoactive substances (Ślęzak 2012; 2016), how they perceive their own body (Ślęzak 2018c), and how they protect themselves against violence and respond to violence (Ślęzak 2017). The transferred knowledge also included ways of reducing the risk related to the provision of sex services and solving emerging dilemmas and problems (cf. Prus and Irini 1988:28).

In addition to coworkers, clients are an extremely important category of interactional partners. They are a distinct group (Marciniak 2010) for the female workers, allowing them to develop their roles in contrast to the role of a client. They may also be the teachers of a role (especially for novice workers), communicating effective ways of conducting commercial meetings during interactions.

I learned a lot from my clients. What they want, how to do the stuff. Because if a client is ok, he will lead you. [woman, 40 years old, 1 year of indoor sex work]

Bosses are a very important category of interactional partners. For novice employees, they are often the source of meanings about whom the person providing the sex services is. In professionally run premises it is easier to adopt a definition of self as a worker. In the case of oppressive places with violence 
against women, the perspective of prostitution as a pathology may dominate, where women have no rights or respect. The difference between these two approaches adopted by the bosses is shown in the following quote (Ślęzak 2019:64, 198):

The boss called us names, which I didn't like at all: "You morons, you idiots, you morons with no school." This killed me the most. [woman, 30 years old, 5 years of indoor sex work]

There is a boss who is an alcoholic, and when he drinks too much, he beats the girls, because he unloads his aggression on these girls. He has two favorites, and the rest are treated very badly. [woman, 41 years old, 2 years of indoor sex work]

There was this client here, and he started, "You whores, fucking bitches." And the girls were like: "What? Are you talking to us?" So we went to our room. And the boss heard it. And he said: "Sir, please leave, you won't insult the girls here." So, such a boss is all right! And in other places, they wouldn't pay attention to this, only MONEY matters. And here, I can't say that. They take care of us, and they pay attention to us. Such a client is asked to leave. [woman, 32 years old, 2 years of indoor sex work]

The attitude of the bosses towards the workers is also imitated by other workers of the premises. It is, therefore, a highly important point of reference that helps to establish who the female workers are and who they are not, in their own eyes, or the eyes of their most frequent interactional partners.

The analysis of the organizational entanglement of the women who provide sex services and the interactional work between the women, the clients, and the agency coworkers makes it possible to in- clude important categories that explain the process of redefining the situation and one's identity. This perspective allows us to understand not only how women are involved in the provision of sex services and how they learn to do this work, but also to discover the dynamics of carrying on with this practice over time. Continuing to work in a particular place depends to a large extent on the interpersonal relations that will be developed between the newcomer and other employees, for example, whether they are going to support her in developing ways of dealing with the risks and difficulties of sex work, or, alternatively, whether they are going to try to make her leave. The different experiences of the women in this regard are shown in the following quotes:

I didn't know what it would actually be like here. I mean, when I started working, the first days I just came here and sat and watched, got to know the girls, and the girls told me about the principles here. They took me in, and I stayed. [woman, 24 years old, 1 year of indoor sex work]

I had a very sad beginning HERE, but there were other girls then. Very upsetting girls. They thought I would go. They did everything so I'd leave on my own accord, but as this was not my first agency, I knew it wouldn't be easy at the beginning...You know, they got pissed off that it didn't work. Everything they did, I just sat and read a book. Because I thought there was no point; if they tease me, what can I talk about with them? So, I brought books, I sat down, and I read, because what could I talk to them about if they did all of that? And they were so pissed off. But, you know, it took a month, a month and a half at most, and they saw that they could do nothing because I just... I came to work at the same time, I did my job, I left, and, you know, they let it go. [woman, 30 years old, 4 years of indoor sex work] 
Effective secondary socialization in agencies equipped the women with the skills to cope with the sex market, not only in social agencies but also in other segments or other roles. An example may be the women who started their sex work career as escort agency workers, and later they gave up that work in favor of individual escorting or starting their own small business, hiring one or two sex workers:

I'd call an agency a private dwelling hatchery. This is where the girls mature before going on to open their own business. Because they have to start somewhere. They prepare to do something similar on their own. And to not share the money with anyone. A LOT of girls from this agency have opened their businesses. You wouldn't believe how many girls actually did come and go, and $3 / 4$ of them have something of their own. [woman, 35 years old, 1 year of indoor sex work]

\section{Conclusions}

I believe that adopting symbolic interactionism as the ontological perspective and grounded theory methodology combined with ethnography as the procedures for studying the social world of escort agencies produced interesting results. This is especially true regarding the literature on the subject that dominates in Poland, which (mostly) adapts the assumptions of a normative paradigm, perceives prostitution as pathology, and which verifies presumed hypotheses rather than giving the stage to the researched individuals.

In my opinion, the elements of my approach that are most interesting for other researchers would be:

- the analysis of sex work provision as a social activity (Prus and Irini 1988:26). Getting involved and carrying on is of a social and not only of an individual and psychological character. Such an approach makes it possible to shift the stress from seeking individual conditions of prostitution to researching the process of sex work. Hence, it is possible to supplement the results of previous (mainly quantitative) research, which point to the social, economic, or psychological factors that contribute to becoming involved in prostitution, with the dimension of interactions between novices and other participants of this social world (Ślęzak 2019:25).

- the analysis of the collective component of identity transformations, which is especially important in the context of escort agencies. Taking up a job in an agency is related to intensive actions by the interactional partners who introduce and socialize the new female workers. They are, therefore, the actors of collective work on redefining the meanings associated with prostitution (Blumer 1969). The multitude of interactional partners in agencies means that the role-making (Turner 1962) process may be very intensive. An escort agency is a place of playing various roles: colleagues, coworkers, a woman providing sex services, a subordinate, a lover, a worker at different stages of her career, et cetera. The dynamics of the interaction between the actors of the escort agency world is of great significance for the women continuing their involvement in prostitution, and it influences the shape of the work and the potential discomfort for the female workers. The collective interactional work of all the social actors involved in the operation of escort agencies keeps the novices in prostitution and makes it difficult for them to leave. This provides clear differentiation between the work in 
the agency and the individual provision of sex services. The former is of a team character and should be researched as such. Thanks to this approach, the researcher may draw special attention to the interactions between the participants of the world of escort agencies and their meaning in the context of both organizational order and actions related to the provision of sex services (Ślęzak 2019:26).

- the analysis of the organizational context of the provision of sex services and its impact on how they are provided and for how long (in a biographical sense). The everyday experiences of remaining in the agency are related to playing social roles that result from membership in the organization. Adapting the micro-sociological perspective makes it possible to analyze the group processes (previously committed in the research) that take place, where several (or even a dozen) people cooperate within a common and not very sizable space. In turn, looking at

\section{References}

Angrosino, Michael. 2010. Badania etnograficzne i obserwacyjne [Doing Ethnographic and Observational Research]. Warsaw: Wydawnictwo Naukowe PWN.

Antoniszyn, Michał and Andrzej Marek. 1985. Prostytucja $w$ świetle badan kryminologicznych [Prostitution in the Light of Criminological Research]. Warsaw: Wydawnictwo Prawnicze.

Ashforth, Blake E. and Glen E. Kreiner. 1999. “'How Can You Do It?': Dirty Work and the Challenge of Constructing a Positive Identity." The Academy of Management Review 24(3):413434.

Becker, Howard. 1953. "Becoming a Marihuana User." The American Journal of Sociology 59(3):235-242. the escort agencies from the perspective of the sociology of work allows us to pay attention to the processes of adaptation and socialization, and the interactions with the boss, coworkers, and clients (Ślęzak 2019:25).

Therefore, the work situation in an escort agency results from the joint actions of numerous individuals who guarantee the infrastructure, the safety, and the flow of clients, and, last but not least, those who provide the sex services (cf. Becker 1982:34; see also: Blumer 1969). The constant attunement between particular members of the team (female workers, security staff, boss) and clients is of key importance (cf. articulation work [Strauss et al. 1985:151-191; Ślęzak 2019:226).

Adapting the proposed analytical perspective allows us to see prostitution not just as a status and the result of particular conditions, but as a process that takes place in given organizational surroundings (Ślęzak 2019). I believe it provides many new questions within the sex work research.

Becker, Howard. 1963. Outsiders. Studies in the Sociology of Deviance. New York: Free Press of Glencoe.

Becker, Howard. 1982. Art Worlds. Oakland, CA: University of California Press.

Becker, Howard S. et al. 1961. Boys in White. Chicago: University of Chicago Press.

Blumer, Herbert. 1969. Symbolic Interactionism. Perspective and Method. Englewood Cliffs, NJ: Prentice-Hall.

Błońska, Barbara. 2010. Zjawisko prostytucji w Polsce w świetle badań kryminologicznych [Prostitution in Poland in the Light of Criminological Research]. Ph.D. dissertation, University of Warsaw. 
Cooley, Charles H. 1922. Human Nature and the Social Order. New York: Charles Scribner's Sons.

Drew, Shirley K., Melanie B. Mills, and Bob M. Gassaway. 2007a. "Introduction". Pp 1-7 in Dirty Work. The Social Construction of Taint, edited by S. K. Drew, M. B. Mills, and B. M. Gassaway. Waco: Baylor University Press.

Drew, Shirley K., Melanie B. Mills, and Bob M. Gassaway. 2007b. "Concluding Thoughts". Pp. 233-243 in Dirty Work. The Social Construction of Taint, edited by S. K. Drew, M. B. Mills, and B. M. Gassaway. Waco: Baylor University Press.

Dziuban, Agata and Anna Ratecka. 2018. "Sprostytuowane, zranione, wrobione: konstruowanie reprezentacji pracownic seksualnych w dyskursie abolicyjnym [Prostituted, Wounded, Framed: Constructing a Representation of Sex Workers in the Abolition Discourse]." LUD 101:171-202.

Gagnon, John H. and William Simon. 1973. Sexual Conduct: The Social Sources of Human Sexuality. Chicago: Aldine.

Gardian, Renata. 2007. Zjawisko sponsoringu jako forma prostytucji kobiecej [Sponsorship as a Form of Female Prostitution]. Cracow: Oficyna Wydawnicza Impuls.

Glaser, Barney and Anselm L. Strauss. 1967. The Discovery of Grounded Theory. Strategies for Qualitative Research. New York: Aldine Publishing Company.

Gobo, Giampietro. 2008. Doing Ethnography. Los Angeles, London, New Delhi, Singapore: Sage.

Goffman, Erving. 1959. The Presentation of Self in Everyday Life. Garden City, NY: Doubleday.

Goffman, Erving. 1961. Asylums: Essays on the Social Situation of Mental Patients and Other Inmates. Garden City, NY: Doubleday.

Goffman, Erving. 1963. Stigma: Notes on the Management of Spoiled Identity. Englewood Cliffs, NJ: Prentice-Hall.

Heap, Chad. 2003. "The City as a Sexual Laboratory: The Queer Heritage of the Chicago School." Qualitative Sociology 26(4):457487.

Hughes, Everett C. 1964. Men and Their Work. Glencoe, IL: Free Press.

Hughes, Everett C. 1997. "Careers." Qualitative Sociology 20(3):389-397.
Izdebski, Zbigniew. 2012. Seksualność Polaków na poczatcu XXI wieku. Studium badawcze [Sexuality of Poles at the Beginning of the 21st Century. Research Study]. Cracow: Wydawnictwo Uniwersytetu Jagiellońskiego.

Jasińska, Magdalena. 1967. Proces społecznego wykolejania młodocianych dziewczat [The Process of Social Derogation of Adolescent Girls]. Warsaw: Wydawnictwo Prawnicze.

Jędrzejko, Mariusz. 2006. Prostytucja jako problem społeczny, moralny i zdrowotny [Prostitution as a Social, Moral, and Health Issue]. Warsaw: Aspra.

Karpiński, Marek. 1997. Najstarszy zawód świata. Historia prostytucji [The Oldest Profession in the World. History of Prostitution]. Berkshire: Lemur.

Kleinknecht, Steven. 2007. "An Interview with Robert Prus: His Career, Contributions, and Legacy as an Interactionist Ethnographer and Social Theorist." Qualitative Sociology Review 3(2):221-288.

Konecki, Krzysztof T. 1988. "Praca w koncepcji socjologii interakcjonistycznej [Work in the Lens of Interactionist Sociology]." Studia Socjologiczne 1(108):225-245.

Konecki, Krzysztof T. 2000. Studia z metodologii badań jakościowych. Teoria ugruntowana [Studies in the Methodology of Qualitative Research. Grounded Theory]. Warsaw: Wydawnictwo Naukowe PWN.

Konecki, Krzysztof T. 2006. "Procesualne ujęcie organizacji. Interpretatywna socjologia organizacji i zarządzania [Processual Approach to the Organization. Interpretative Sociology of Organization and Management]." Pp. 11-24 in Wspótczesne problemy socjologii organizacji $i$ zarzadzania. Wybrane zagadnienia [Contemporary Issues of the Sociology of Organization and Management. Selected Issues], edited by K. Konecki and B. Glinka. Lodz: Wydawnictwo Uniwersytetu Łódzkiego.

Konecki, Krzysztof T. 2007. “Nowi pracownicy a kultura organizacyjna przedsiębiorstwa. Studium folkloru fabrycznego [New Employees and the Organizational Culture of the Enterprise. A Study of Factory Folklore]." Przeglad Socjologii Jakościowej 3(1):1-126.

Kowalczyk-Jamnicka, Małgorzata. 1998. Społeczno-kulturowe uwarunkowania prostytucji w Polsce [Socio-Cultural Determinants of Prostitution in Poland]. Bydgoszcz: Wydawnictwo Wyższej Szkoły Pedagogicznej. 
Leznoff, Maurice and William A. Westley. 1956. "The Homosexual Community." Social Problems 3:257-263.

Lombroso, Cesare and Guglielmo Ferrero. 2004. Criminal Woman, the Prostitute, and the Normal Woman. London: Duke University Press.

Marciniak, Łukasz. 2010. “Konstruowanie tożsamości zawodowej: procesy odniesienia i rozróżnienia [Constructing Professional Identity: Reference and Differentiation Processes]." Pp. 181-195 in Symboliczno-interakcyjny wymiar konstruowania ładu i nieładu społecznego [The Symbolic and Interactional Dimension of the Constitution of Social Order and Disorder], edited by K. T. Konecki and A. Kacperczyk. Lodz: Wydawnictwo UŁ.

Podgórecki, Adam. 1969. Patologia życia społecznego [Pathology of Social Life]. Warsaw: PWN.

Pospiszyl, Irena. 2008. “Prostytucja [Prostitution]”. Pp. 224-245 in Patologie społeczne [Social Pathologies], edited by I. Pospiszyl. Warsaw: Wydawnictwo Naukowe PWN.

Prus, Robert. 1996. Symbolic Interaction and Ethnographic Research. Intersubjectivity and the Study of Human Lived Experience. New York: State University of New York Press.

Prus, Robert. 2009. "Hookers, Rounders and Desk Clerks: Encountering the Reality of the Hotel Community." Pp. 238-250 in Ethnographies Revisited. Constructing Theory in the Field, edited by A. J. Puddephatt, W. Shaffir, S. W. Kleinknecht. London: Routledge.

Prus, Robert and Scott Grills. 2003. The Deviant Mystique: Involvements, Realities and Regulation. Westport, CT: Praeger.

Prus, Robert and Styllianos Irini. 1988. Hookers, Rounders and Desk Clerks. The Social Organization of the Hotel Community. Salem: Sheffield Publishing Company.

Reckless, Walter. C. 1933. Vice in Chicago. Chicago: University of Chicago Press.

Reiss, Albert J., Jr. 1961. “The Social Integration of Queers and Peers." Social Problems 9:102-120.

Roberts, Nickie. 1992. Whores in History. Prostitution in Western Society. London: Harper Collins.

Sanders, Teela. 2006. "Sexing Up the Subject: Methodological Nuances in Researching the Female Sex Industry." Sexualities 9(4):449-468.
Shibutani, Tamotsu. 1962. "Reference Group and Social Control." Pp. 128-147 in Human Behavior and Social Processes. An Interactionist Approach, edited by A. M. Rose. Boston: Houghton Mifflin Company.

Strauss, Anselm and Juliet Corbin. 1990. Basics of Qualitative Research. London: Sage.

Strauss, Anselm L. et al. 1985. Social Organization of Medical Work. Chicago, London: The University of Chicago Press.

Surmiak, Adrianna. 2015. Antropologia kłamstwa. O sposobach interpretacji kłamstwa na przykładzie społeczności katolickiego Ośrodka Interwencji Kryzysowej [The Anthropology of Lies. On the Ways of Interpreting a Lie on the Example of the Catholic Crisis Intervention Center Community]. Cracow: Nomos.

Sykes, Gresham M. and David Matza. 1957. “Techniques of neutralization: A Theory of Delinquency." American Sociological Review 22(6):664-670.

Szczepański, Jan. 1961. “Uwagi o przedmiocie i zadaniach socjologii [Notes on the Subject and Tasks of Sociology]." Pp. 169-184 in Jak pracuje czlowiek. Z badań polskich psychologów, socjologów i ekonomistów [How People Work. From the Research of Polish Psychologists, Sociologists and Economists], edited by B. Biegeleisen-Żelazowski et al. Warsaw: Książka i Wiedza.

Ślęzak, Izabela. 2010. “Być prostytutką - problematyka konstruowania tożsamości kobiet prostytuujących się [Being a Prostitute-The Issue of Constructing the Identity of Women in the Sex Industry]". Pp. 293-311 in Symboliczno-interakcyjny wymiar konstruowania ładu i nieładu społecznego [The Symbolic and Interactional Dimension of the Constitution of Social Order and Disorder], edited by K. T. Konecki and A. Kacperczyk. Lodz: Wydawnictwo UŁ.

Ślęzak, Izabela. 2012. "Alcohol Use as a Work Factor among Female Sex Workers in Escort Agencies." Alcoholism and Drug Addiction 25(4):E33-E52.

Ślęzak, Izabela. 2014. “Kolektywny wymiar budowania zaangażowania $\mathrm{w}$ pracę seksualną kobiet świadczących usługi seksualne $\mathrm{w}$ agencjach towarzyskich [The Collective Dimension of Building Involvement in Sexual Work of Women Providing Sexual Services in Escort Agencies]." Przeglad Socjologii Jakościowej 10(4):56-79.

Ślęzak, Izabela. 2016. “Causes and Strategies of Limiting Psychoactive Substance Use by Female Escort Agency Sex Workers." Alcoholism and Drug Addiction 29(3):103-129. 
Ślęzak, Izabela. 2017. “Violence Towards Sex Workers. Analysis Based on Research into the Field of Indoor Sex Work in Poland." Polish Sociological Review 2:237-254.

Ślęzak, Izabela. 2018a. "Praca nad zaufaniem. Etyczne, praktyczne i metodologiczne wyzwania w relacjach badacz-badani na przykładzie etnografii agencji towarzyskich [Working on Trust. Ethical, Practical, and Methodological Challenges in the Researcher-Respondents Relations on the Example of the Ethnography of Escort Agencies]." Przeglad Socjologii Jakościowej 14(1):138-162.

Ślęzak, Izabela. 2018b. "Research on Indoor Sex Work in Poland-An Ethnographer's Dilemmas." Oñati Socio-Legal Series 8(8)1134-1150.

Ślęzak, Izabela. 2018c. "A Present and a Non-Present BodyExperiencing the Body by Female Sex Workers in Commercial Sexual Relations." Qualitative Sociology Review 14(2):30-50.
Ślęzak, Izabela. 2019. Social Construction of Sex Work. Ethnography of Escort Agencies in Poland. Lodz, Cracow: Wydawnictwo UŁ, Jagiellonian University Press.

Thomas, Wiliam. 1923. The Unadjusted Girl: With Cases and Standpoint for Behavior Analysis. Boston: Little Brown and Company

Turner, Ralf. 1962. "Role-Taking: Processes versus Conformity." Pp. 20-40 in Human Behavior and Social Processes, edited by A. Rose. Boston: Houghton Mifflin.

Wojciechowska, Magdalena. 2012. Agencja towarzyska - (nie) zwykte miejsce pracy [The Escort Agency-An (Extra)Ordinary Workplace]. Cracow: Nomos.

Welskop, Wojciech. 2013. Zjawisko prostytucji w Polsce po 1989 roku [The Phenomenon of Prostitution in Poland after 1989]. Torun: Wydawnictwo ECE.

\section{Citation}

Ślęzak, Izabela. 2020. "An Ethnographic Analysis of Escort Services in Poland: An Interactionist Approach." Qualitative Sociology Review 16(4):122-144. Retrieved Month, Year (http://www.qualitativesociologyreview.org/ENG/archive_eng.php). DOI: http:// dx.doi.org/10.18778/1733-8077.16.4.08 